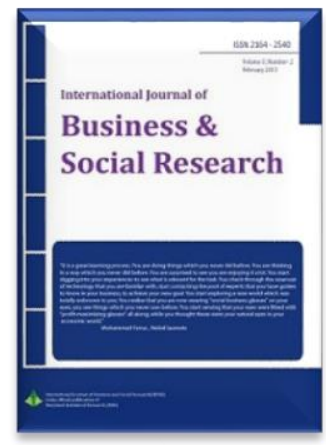

\title{
Evaluation Environmental Indicators: A Case Study of Public and Private Resorts in Lagos state, Nigeria
}

\author{
Funmilola Ajani', Haminat Abisola Adedoyin ${ }^{2}$
}

\begin{abstract}
Tourism has a major impact on natural and built environments, also on the wellbeing and culture of host populations. These effects can be positive or negative, depending on how tourism is developed and managed. This study aimed at evaluating the environmental quality and management of Whispering Palms Resort (private establishment) and Suntan Beach Resort (Government-owned). We use direct observation of the environment, structured questionnaires to the tourists as well as laboratory analysis of soil and water sample from the two sites for Total Coliform Count and Total Aerobic Count. Results show that Whispering Palms Resort is of higher quality with $70.9 \%$ while Suntan Beach had 47.4\%. Facilities and services assessment shows that Whispering Palms Resort was rated high with $61.8 \%$, and Suntan Beach Resort had $47.4 \%$. Furthermore, the mean Total Aerobic Count and Total Coliform count obtained from soil and water sample exceeded USEPA standard for recreational waters, which should not exceed $500 \mathrm{cell} / 100 \mathrm{ml}$. We recommend that proper monitoring should be carried out on a regular basis to ensure clean and safe environment.
\end{abstract}

Keywords: Anthropogenic activities, Total coliform count, Total aerobic count, USEPA.

Available Online: 12-08-2016

This is an open access article under Creative Commons Attribution 4.0 License, 2016.

\section{$1.0 \quad$ INTRODUCTION}

Tourism and the environment are inter-dependent. The natural and man-made environments provide many attractions to tourists, and the development of tourism creates both positive and negative environmental impacts. Beach area is one of the most sorted recreational sites for people within, around or far from the sites. However, tourist satisfaction and safety regarding facilities, services and quality of the environment are of great importance. Beach ecosystems are affected by many different types of human pressure, from recreation activities to coastal armoring. Environmental hazards are majorly

\footnotetext{
1 Senior lecturer, Department of Wildlife and Ecotourism Management, University of Ibadan, Ibadan, Nigeria. E-mail: funmilolajani@yahoo.com; f.ajani@ui.edu.ng, Phone:+2348039694175

${ }^{2}$ Department of Wildlife and Ecotourism Management, University of Ibadan, Ibadan, Nigeria. E-mail: +2348092454222
} 
caused by anthropogenic activities, resulting in pollution and generation of waste product which is left at the beach.

The question of sustainability is particularly important in the context of coastal tourism, which is an activity at the interface of humankind, land, and water (Al-Jebouri and Edham, 2012). Coastal tourism, therefore, is facing the challenge of balancing tourism's economic advantages with maintaining environmental sustainability and the inevitable change of its character with the progress of time. The sea beaches perform in this context, a fundamental role where the issues related to planning and management are increasingly more important when it comes to the implementation of sustainable development strategies (Silva et al., 2006).

Recreational uses of inland and marine waters are increasing in many countries worldwide. These uses range from whole-body water contact sports, such as swimming, surfing, and slalom canoeing, to noncontact sports, such as fishing, walking, bird watching and picnicking. The hazards that are encountered in recreational water environments vary from site to site, as do the nature and extent of exposure. Most available information relates to health outcomes arising from exposure through swimming and ingestion of water. Indicators are information sets which are formally selected to be used on a regular basis to measure changes that are of importance for tourism development or management (UNWTO, 2004). Indicators such as faecal coliform, enterococci, and E.coli has been successfully used in advanced countries to determine the environmental integrity of recreational water bodies and the beach sand. Beach sands have become increasingly recognized worldwide as sources of non-point contamination for their ability to harbor bacteriological indicators and influence recreational water quality (Whitman and Nevers, 2003). Environmental indicators look at the effect of human activities on the environment as well as the implication of those actions on human health, quality of life and the integrity of the ecosystem. Since soil microorganisms can respond rapidly, they reflect a hazardous environment and are, therefore, considered when monitoring soil status.

Olayiwola (2014) worked on the assessment of tourism potentials of Lagos State while Mobee (2014) assessed the tourism potentials of Badagry local government area, Lagos State. Olaoluwa (2015) worked on the assessment of sustainable tourism development services of Whispering Palms, Badagry and Adewale (2015) assessed economic and socio-cultural tourism indicators for Suntan Beach, Badagry. However, there is a dearth of knowledge concerning proper documentation on environmental quality, and management of Whispering Palms Resort and Suntan beach resort and this project is to fill this gap. Hence, this study covers two different resort centres in Badagry, Lagos state, which are: Whispering Palms Resort (Private-owned) and Suntan Beach Resort (Government-owned).

The main objective of this research is to evaluate some environmental indicators of Whispering Palms Resort and Suntan Beach Resort while the specific objectives are to assess the impact of tourism on the environment of the beaches and to determine the microbial load in the beach sand and water at the beaches.

\subsection{METHODOLOGY}

\section{$2.1 \quad$ STUDY AREA}

Lagos state is located in the Southwestern part of Nigeria with a total land area of $3,577 \mathrm{~km}^{2} .22 \%$ of its $3,577 \mathrm{~km}^{2}$ are lagoons and creeks. It is bounded by Ogun State in the North and East, in the West it shares boundaries with the Republic of Benin and in the South lies the Atlantic Ocean (Wikipedia, 2015). The study area for this research is Badagry local government area of Lagos state. Lagos state is located in the South Western geopolitical zone of Nigeria which has Ikeja as its capital. The average temperature in Lagos is $27^{\circ} \mathrm{C}$.

\subsection{DEMOGRAPHY OF STUDY AREA}


Lagos State is inhabited by the Aworis and Ogus in Ikeja and Badagry divisions respectively, with the Ogus being found mainly in Badagry while the indigenous population of Lagos is Aworis. Nevertheless, there is a mixture of other pioneer immigrant settlers collectively called Lagosians. The indigene of Ikorodu and Epe divisions are mainly the ljebus with pockets of Eko-awori settlers along the coastland and riverine areas. While the state is essentially Yoruba speaking environment, it is nevertheless a socio-cultural melting point attracting both Nigerians and foreigners alike.

\subsection{SHORT HISTORY OF STUDY AREAS}

The ancient city of Badagry is located in Southwestern part of Nigerian border with the Benin Republic. It is located at latitude $6.5^{\circ} \mathrm{N}$ of the Equator and longitude $3.25^{\circ} \mathrm{E}$ of the Greenwich Meridian. It is bounded on the West by Porto Novo and Seme, on the North by Ilogbo, Ipokia, on the South by the Osa lagoon and the Atlantic Ocean on the East. Badagry has the Awori settlements of Ojo and Lagos. As a result of its strategic location, Badagry became a cultural transition zone at a time in its history. The municipality has a population of 241,093 and total land size of $441 \mathrm{~km}^{2}$.

As a result of this rich history spanning four centuries, Badagry has become a major tourism destination along the ancient Slave Coast of West Africa.

Figure 1: Map of Lagos state is indicating the study site in the red coloured arrow (Badagry).

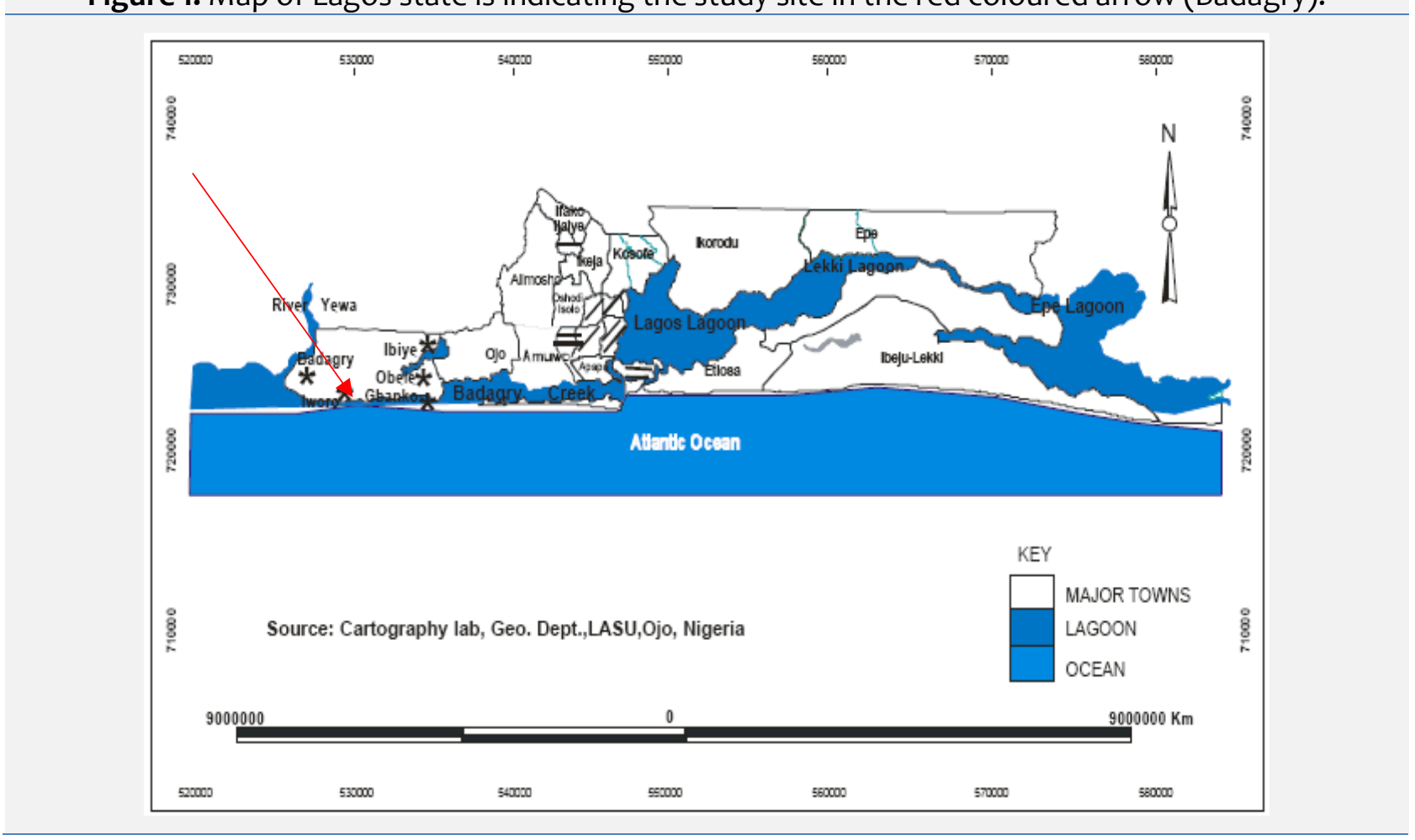

\subsection{WHISPERING PALMS RESORT}

Whispering Palms is a resort centre occupying an 8(12) - acres of land in a rural area at Iworo - Ajido, Badagry Local Government Area, Lagos state. The embryonic phase began in February 1981 with the acquisition of the primary grounds by Professor Deji Femi Pearse.

Whispering Palms Resort lies on the lagoon and typifies the beauty of the area-cool Atlantic breeze, silica sands, palm trees and chirping birds. The road within the resort looks fascinating as it is lined with palm kernel, accessibility is by road and speed boat. The entire environment is quiet with stunning ambience. It has well equipped rooms for tourists accommodation in different shades and sizes; 5 mini suites, 72 
double rooms, 3 Atlantic suites and 40 executive wings. Recreational facilities available in the resort are world class swimming pool, sports area (larus field) close to the lodges, museum, Art gallery, Angela bike and boat to cruise on the lagoon which is for rent to tourists.

\subsection{SUNTAN BEACH}

Suntan Beach is located about four miles from the centre city of Badagry, and seven miles from Seme border. Suntan Beach, which is also known as "coconut beach" is a beautiful beach in the coastal town of Badagry, west of Lagos. It was established in 1999 and commissioned in 2000 by the local government chairman, Honourable Moses Owolabani, who had experience in hospitality by working with Eko Hotel for 22 years. This undoubtedly marked the beginning of the blooming of tourism in the community with the aim to generate more revenue for the local government and employment for the residents within and around the host communities. The beach is surrounded by two villages called Fanuvi and Sakpo which are about 20 miles towards the border of Nigeria and Republic of Benin. It is accessible through the LagosBadagry Expressway.

A beach is an attractive place which accommodates more than 5000 tourists during public holidays and festive periods (peak periods). The resort has chalet which provides accommodation for tourists who intends to spend more than one day.

About sixty (60) well-arranged straw or asbestos - huts are available for rent to tourists at the beach. Other sources of income generation include horse riding and photography. Beach balls and swimming are some of the recreational activities being enjoyed by tourists. Souvenirs available at the beach for sale include rafian hats, bags, beads, and purse. Also, mini bar, restaurants, spacious car park, a standard stage for entertainment and police station outside the beach to ensure maximum security of tourists are some of the social facilities available at the beach resort.

\subsection{RESEARCH METHODS}

The research methods used includes administration of questionnaires to tourists, semi-structured interview with the key informant, laboratory analysis on samples of beach soil and water collected from the resorts.

\subsection{SAMPLING AND SAMPLING TECHNIQUES}

\subsubsection{SAMPLING SIZE}

One hundred and twelve consenting tourists (55 and 57) from Whispering Palms and Suntan Beach respectively were selected by using simple random sampling method in the two study sites. These sites were selected so as to allow for comparison between Whispering Palms, a private- owned tourism center and Suntan Beach, a local government-owned tourism site.

\subsection{METHODS OF DATA COLLECTION}

A reconnaissance survey was made to the study sites to get familiar with the study site, identify the facilities, services, and the environment. Primary data and secondary data were obtained. Open and closed ended questionnaire were administered to the tourists. Open ended questions were used to solicit for respondent responses on various issues under study, which enabled them to give their varied views based on their experience and observations, while closed ended questions were used to solicit their responses based on the Likert type scale whose values ranges 1-5 on the rating scale. A total of 112 questionnaires were self-administered and all were retrieved for analysis. 
his method was used to source for information using semi-structured questions to obtain information from the key informant concerning the maintenance of facilities and the environment of the beaches.

\subsection{COLLECTION OF SOIL SAMPLE}

$30 g$ of soil sample from three different points were collected in a sterilized bottle in replicates at a distance of 50 meters apart from the point where recreational activities were carried out on the same day at the two study sites by $9.00 \mathrm{am}$. Samples collected were labeled immediately, packed in a box filled with ice packs to maintain the temperature and transported within two hours to the laboratory for analysis.

\subsection{COLLECTION OF WATER SAMPLE}

Water samples were collected in replicates in sterilized 100ml bottle from three different points in replicates at the two study sites, at a distance of 50,100 and 150 meters into the recreational water, where tourists swim and boat- cruise by $9.00 a m$. This was immediately labeled and packed in ice- filled box, which was transported to the laboratory for analysis within two hours from collection.

\subsection{LABORATORY ANALYSIS}

The analysis was carried out on beach sand and a water sample from the two sites for Total Coliform Count and Total Aerobic Count. Serial dilution of the soil and water samples from the beach was carried out at 3 -fold and 5 -fold dilutions using peptone water $100 \mathrm{ul}(0.1 \mathrm{ml})$.

\subsection{INOCULATION OF WATER AND SOIL SAMPLES}

$0.1 \mathrm{ml}$ from each of the samples (water and homogenized soil sample) was inoculated on the prepared Plate Count Agar and Mac Conkey agar plates and incubated at $37^{\circ} \mathrm{C}$ for $18-24$ hours, for the total aerobic count and total coliform count respectively. Following inoculation, discrete bacterial colonies were counted from the incubated Nutrient agar plates and Mac Conkey agar plates using the colony counter.

\subsection{DATA ANALYSIS}

Data collected through questionnaires were coded, analyzed and relationships between variables were derived using cross-tabulation, with the use of SPSS. Descriptive statistics were used to determine frequencies and percentages while inferential statistical analysis (chi-square), was used to determine whether expected frequencies differ from the actual frequencies.

The result that was obtained from laboratory analysis was converted to log and plotted as bar charts.

\subsection{RESULTS}

Demographic variables of respondents are as shown in Table 1.

\begin{tabular}{lrr}
\hline \multicolumn{3}{c}{ Table 1: Demographic variables of respondents $(\mathrm{n}=112)$} \\
\hline Variables & Frequency & Percentage \\
\hline Gender of respondents & 78 & 69.6 \\
Male & 34 & 30.4 \\
Female & & \\
Age & 10 & 9 \\
$\leq 20$ & 50 & 44.7 \\
$21-30$ & 36 & 32.3 \\
$31-40$ & & \\
\hline
\end{tabular}




\begin{tabular}{lrr}
\hline$\geq 41$ & 16 & 14.4 \\
Occupation & & \\
Civil servant & 20 & 17.9 \\
Farming & 10 & 8.9 \\
Teaching & 9 & 8.0 \\
Artisan & 14 & 12.5 \\
Others & 59 & 52.7 \\
Educational qualification & & \\
Vocational & 6 & 5.4 \\
Primary & 5 & 4.5 \\
SSCE & 18 & 16.1 \\
OND/HND & 26 & 23.2 \\
B.Sc & 38 & 33.9 \\
M.Sc & 14 & 12.5 \\
Others & 5 & 4.5 \\
Geo-political zone & & \\
North -East & 3 & 2.7 \\
North -Central & 7 & 6.3 \\
South -East & 23 & 20.5 \\
South -West & 66 & 58.9 \\
South -South & 13 & 11.6 \\
Marital status & & \\
Single & 45 & 40.2 \\
Married & 66 & 58.9 \\
Divorced & 1 & 0.9 \\
\hline & & \\
\hline
\end{tabular}

3.1 RESPONDENTS RESPONSES TO STATEMENT ON ENVIRONMENTAL ASPECT OF THE BEACHES

Table 2: Respondents responses to statement on environmental aspect of the beaches

\begin{tabular}{|c|c|c|c|}
\hline $\mathrm{S} / \mathrm{N}$ & Statements & Mean of Suntan Beach & Mean of Whispering Palms \\
\hline 1. & Waste product on sand & 1.9 & 1.2 \\
\hline 2. & Waste in water & 1.8 & 1.3 \\
\hline 3. & Toilet facilities & 1.7 & 1.2 \\
\hline 4. & Shower facilities & 1.8 & 1.0 \\
\hline 5. & Toilet maintenance & 2.0 & 1.0 \\
\hline 6. & Shower maintenance & 1.6 & 1.2 \\
\hline 7. & Rain water run-off & 1.3 & 1.1 \\
\hline 8. & Presence of vegetation & 1.3 & 1.2 \\
\hline 9. & Presence of oil on water & 1.1 & 1.1 \\
\hline 10. & Presence of oil on sand & 1.1 & 0.9 \\
\hline 11. & Noise of engine and vehicle & 1.4 & 1.2 \\
\hline 12. & Noise of people & 1.9 & 1.3 \\
\hline 13. & Emission of toxic substances & 1.3 & 0.9 \\
\hline
\end{tabular}

Table 2 below shows the response of respondents from Whispering Palms and Suntan Beach to statement on the environmental aspect of the beaches which was rated from "Extremely serious environmental problem" $=5$,Very serious environmental problem $=4$, Serious environmental problem=3,Mild environmental problem $=2$ and "No environmental problem" $=1$.

\subsection{DISTRIBUTION OF RESPONDENTS BASED ON THEIR RESPONSES TO STATEMENTS ON FACILITIES AND SERVICES AT THE RESORTS}


Table 3 below shows the general response of respondents from Whispering Palms and Suntan Beach to statement on facilities and services rendered by the resort centers which was rated from excellent $=5$ ,Very good $=4$, Good=3,Fair $=2$ and bad $=1$.

Table 3: Distribution of respondents based on their responses to statements on facilities and services at the resorts

\begin{tabular}{llrr}
\hline S/N & Statements & Mean of Suntan Beach & Mean of Whispering Palms \\
\hline 1. & Accessibility & 3.2 & 1.8 \\
2. & Condition of facilities & 2.6 & 3.4 \\
3. & Cleanliness of the beach & 3.1 & 3.6 \\
4 & Friendliness of the people & 3.4 & 3.4 \\
5 & Quality of tourism & 3.3 & 3.6 \\
6 & Level of safety & 3.2 & 3.2 \\
7 & Information on beach condition & 2.8 & 3.0 \\
8 & Uniqueness of attraction \& services & 2.5 & 3.5 \\
9 & Quality of water & 2.9 & 3.2 \\
10 & Parking area & 3.4 & 3.7 \\
11 & Attractive views & 3.0 & 3.7 \\
12 & Restaurant\& bar & 3.0 & 3.4 \\
13 & Play/sport area & 3.1 & 3.9 \\
14 & Rentals of sunshade & 3.3 & 3.1 \\
15 & Areas for water recreation activities & 3.0 & 3.1 \\
16 & Surveillance & 3.1 & 3.2 \\
17 & Toilet facilities & 2.1 & 3.3 \\
\hline
\end{tabular}

\subsection{RESULT OF CHI SQUARE ANALYSIS BETWEEN ENVIRONMENTAL QUALITY OF WHISPERING PALMS AND SUNTAN BEACH RESORT}

Table 4 shows that there is a significant big difference between the environmental quality of Whispering Palms and Suntan beach resort. This cannot be dissociated with the fact that Whispering Palms is a private-owned resort center.

Table 4: Relationship between environmental quality at whispering palms and suntan beach

\begin{tabular}{lrrr}
\hline Variables & K-value & t-value & p-value \\
\hline Environmental quality & 110 & -2.738 & $0.000^{*}$ \\
\hline$P^{*}<0.05=$ significant & & & \\
\hline
\end{tabular}
WHISPERING PALMS AND SUNTAN BEACH RESORTS

Table 5 shows that there is a significant difference between the facilities and services rendered at Whispering Palms and Suntan Beach.

Table 5: Relationship between facilities and services at Whispering Palms and Suntan Beach

\begin{tabular}{lrrr}
\hline Variables & K-value & t-value & p-value \\
\hline Facilities Vs Services & 110 & 0.002 & $0.053^{*}$ \\
\hline $\mathrm{P}^{*}<0.05=$ significant & & & \\
\hline
\end{tabular}

\section{5}




\subsubsection{TOTAL AEROBIC COUNT OF SOIL SAMPLE}

Figure 2 shows that the highest mean was obtained from Suntan Beach which is 891cells/10oml at a distance of 50 meters while Whispering Palms had 885 cells/10oml. The two resorts had the same mean at a distance of 100 meters which is 863 cells/100ml. Also, Whispering Palms had the lowest mean which is 847 cells $/ 100 \mathrm{ml}$ at a distance of 150 meters.

Figure 2: Total aerobic count on soil sample

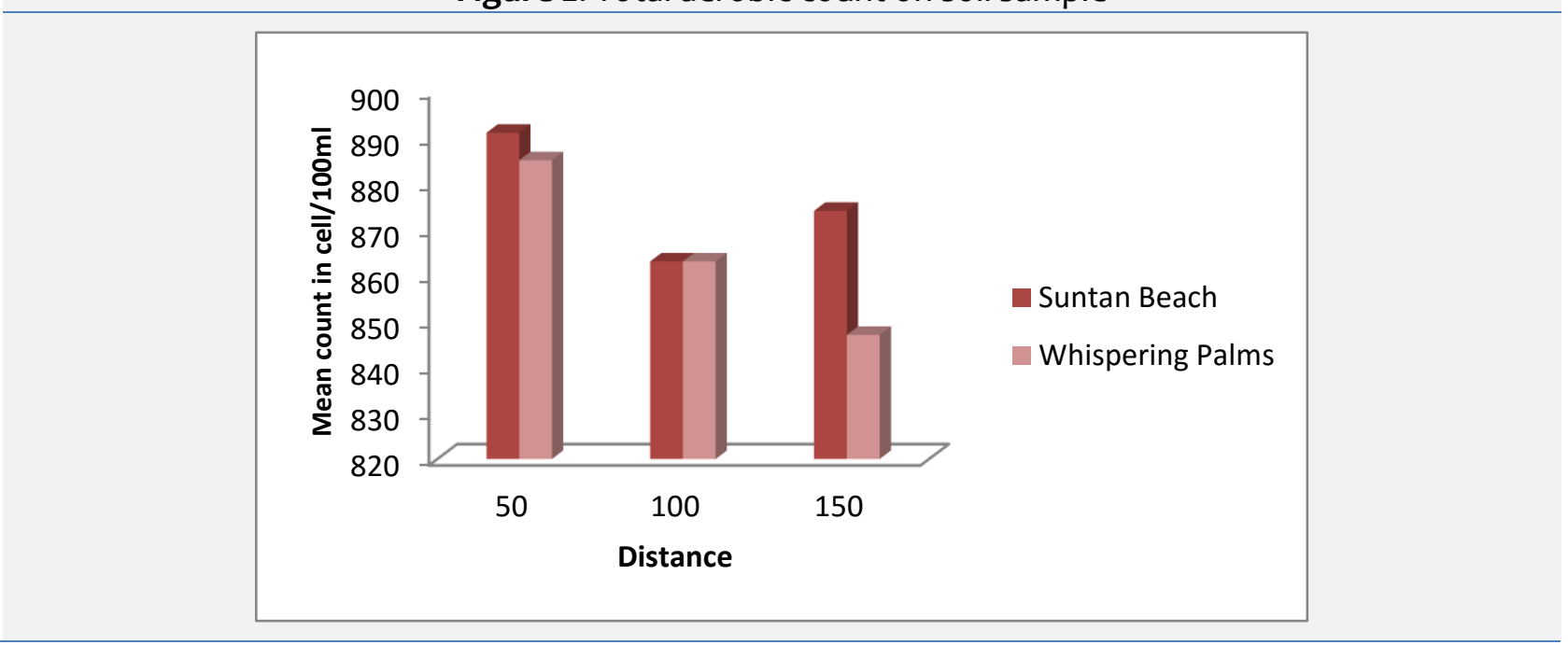

\subsubsection{TOTAL AEROBIC COUNT ON WATER SAMPLE OF THE SWIM AREA}

The mean for Whispering Palms at 50meters was 871cells/100ml and Suntan Beach was 861cells/100ml, while at a distance of 100 meters Suntan Beach had the lowest mean which is $854 \mathrm{cell} / 100 \mathrm{ml}$ and Whispering Palms had 864cells/10oml (fig.3).

Figure 3: Total aerobic count on water sample

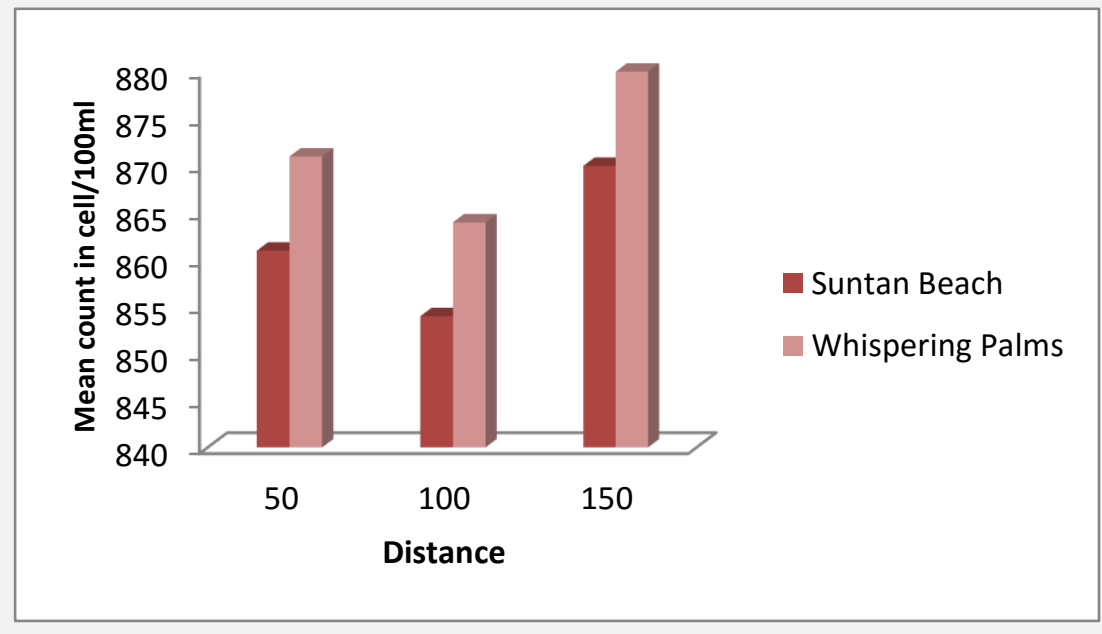

\subsubsection{TOTAL COLIFORM COUNT ON SOIL SAMPLE}

Figure 4 shows that Suntan Beach had the highest mean at a distance of 50 meters (857cells/100ml) and Whispering Palms 847 cells/10oml. At a distance of 100 meters, the mean of the two resorts was the same which is 822 cells/100ml. The mean of Suntan Beach at 150 meters was $835 \mathrm{cells} / 100 \mathrm{ml}$, and Whispering had 815 cells/10oml. 


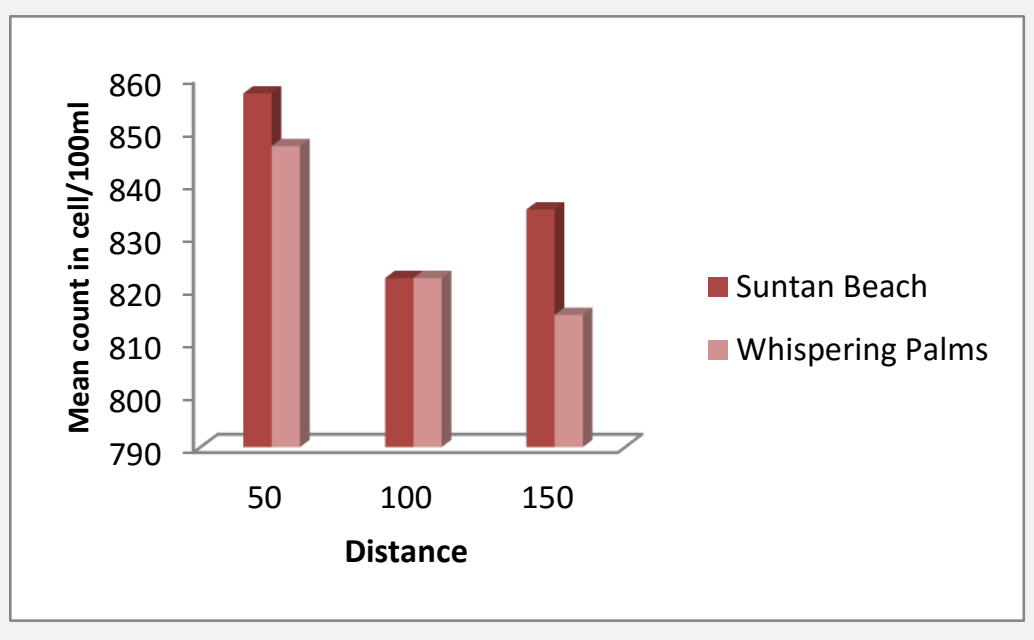

\subsubsection{TOTAL COLIFORM COUNT ON WATER SAMPLE AT THE SWIM AREAS}

Figure 5 shows that Whispering Palms had the highest mean at a distance of 5ometers which is 853 cells/10oml, while Suntan Beach had 817 cells/100ml. At 100 meters the mean of Whispering Palms was 832 cells/100ml and Suntan Beach had 813 cells/100ml while at $150 m e t e r s$, Whispering Palms and Suntan Beach mean had 831cells/100ml and 795cells/100ml respectively.

Figure 5: Total coliform count on water sample

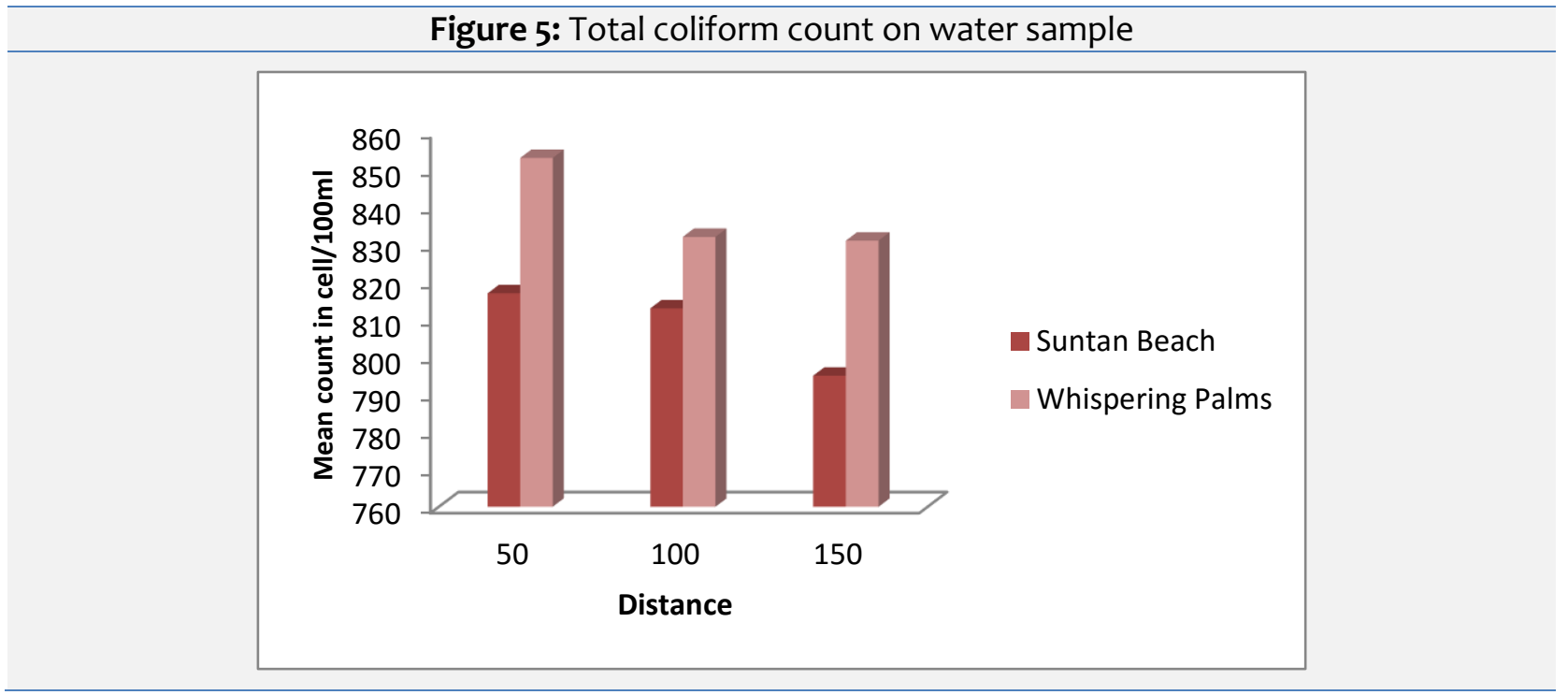

\subsection{DISCUSSION}

Summary of demographic characteristics of respondents (Table 1) shows that majority of the respondents are male (69.9\%), and the mean age of all respondents is 31.3 , which falls within the age group of 21-30. Larger percentages of the respondents are literate with $58 \%$ of the respondents from South-West. Also, the majority of the respondents are married, and all are Nigerians.

Water quality standards are the cornerstone of a state's water quality management program (USEPA, 2003). According to Ibrahim et al., (2013), water quality affects public health. Marine and coastal litter are defined as any item that appears on beaches or at sea as a result of human activity (Storrier et al., 2007). In the case of beaches, it is beach visitors who are responsible for the majority of beach litter, although physical factors such as wind, waves, and tides can also transport litter to the shore from distant sources. The problem of litter on beaches is that it can harm beach and coastal ecosystems and also cause aesthetic degradation resulting in a reduction in the perceived amenity value of the beach (Storrier et al., 
2007). No litters were observed in water at Whispering Palms while some litters were observed at Suntan Beach, which constitutes mild environmental problem.

For toilet and shower facilities (Table 3), Suntan Beach had mild environmental problem but there was no environmental impact in Whispering Palms because it was observed that they have good toilet and shower facilities, constructed at different locations in the resort for easy assess to tourists whereas Suntan Beach do not have enough toilet and shower facilities which most of the tourists complain of. Cleaning of the recreational beaches is paramount. According to Tudor and Williams (2008), proper beach cleaning and maintenance of facilities results in rising of beach aesthetic amenity standards. There was no environmental impact caused by rain water run-off because the landscape was well designed at the two resorts. Both Suntan Beach and Whispering Palms had green spaces which added to the aesthetic value of the two resorts, and this was one of the things that attract the tourists to these sites.

Environmental degradation of beaches is known to lead to loss of income from tourism according to US EPA (2003). Ideally, water at swimming areas should be clear enough for users. The aesthetic value of recreational waters implies freedom from visible materials that will settle to form objectionable deposits, floating debris, oil, scum and other matters, substances producing objectionable colour, odour, taste or turbidity and substances and conditions that produce undesirable aquatic life. Considering these two tourist sites for the presence of oil on water (Table 2), Suntan Beach had mean 2.1 which indicates a mild environmental problem and Whispering Palms had a mean of 1.9 which suggests no environmental problem. Suntan Beach had a mild environmental impact due to the noise of people and its location which is along Badagry express way while Whispering Palms do not have this problem because of its quiet, serene place where it is located. No industry was sited within the vicinity of the two resorts as observed during the reconnaissance survey and as reported by the key informants (appendix).

Assessibility to a tourist centre is a key factor affecting the level of patronage of tourists as cited by Ibimilua (2009). Findings on facilities and services show that accessibility to Whispering Palms is the major challenge of the resort due to a bad road network that leads to the place but for Suntan Beach, the road leading to the resort is one of the best in Badagry, making it more assessable. Affluent tourists, however, gain access to Whispering Palms by speed boat. The two resorts had a good remark for a statement on conditions of facilities. Whispering Palms was rated very good on the cleanliness of the beach while Suntan Beach had good. For friendliness of the people, the two resorts were rated good, because both the members of staff and the neighboring communities were accommodating.

A poor infrastructural development like accommodation, according to Ibimilua (2009), is one of the key factors that impede tourism development in developing countries. Whispering Palms was rated very good regarding the quality of tourism offer; this is because they provide accommodation for tourists who intend to spend more than a day with quality intercontinental and continental dishes, while Suntan Beach was rated good. The total number of a chalet in Whispering Palms sums up to 112 while Suntan Beach have only 10. Safety of tourists is very paramount in ecotourism industry. For this, the two resorts were scored well. It was observed that Suntan Beach had a police station located outside the resort to ensure maximum security of life and properties. Also Whispering Palms have a good security guard on patrol 24 hours. Whispering Palms provide more information on beach condition when compared to Suntan Beach which was scored fair.

Do Valle et al.,(2006) stated that assessing satisfaction could help tourism service managers improve their services. In the uniqueness and attractions of the resorts, Whispering Palms was rated very good by tourists while Suntan Beach had good. Whispering Palms had a very good parking area, while Suntan Beach had good parking area. On attractive views (table 3), Whispering Palms was scored very good while Suntan Beach was rated well by respondents. Whispering Palms have a very cool and well organized area for sports and play than Suntan Beach. The two resorts have good areas for water recreation activities. For surveillance, Whispering Palms and Suntan Beach were scored well. Whispering Palms have good toilet facilities, but Suntan Beach was rated fair, it was also observed that Suntan Beach toilet facilities is insufficient to cater for a large number of tourists at a time. 
According to the key informant (appendix), the average number of tourist during peak period at Whispering Palms is 2,000 while Suntan Beach is 5,000. Suntan Beach do not have catering unit but rather food vendors, unlike Whispering Palms which do not allow tourists to come in with their food because they have a standard catering unit which offers continental and local delicacies. This is a discredit to Suntan Beach. As a cushioning effect, restaurants were situated around it. The two resorts have hotels nearby which tourists use when their carrying capacity has been exceeded. Cases of food poisoning have not experience at the resorts.

According to Okhuysen et al., (1999), recreational waters generally contain a mixture of pathogenic and non-pathogenic microorganisms. These microorganisms may be derived from sewage effluents, the recreational population using the water (from defecation and shedding), livestock (cattle, sheep, etc.), industrial processes, farming activities, domestic animals (such as dogs) and wildlife. Also, recreational waters may also contain free-living pathogenic microorganisms. Findings from the key informants show that there are no factories around the resorts which emit large quantities of polluted substances.

From a recreational viewpoint, sand beaches are sought after. A significant percentage of time is spent on the beach itself rather than in the water. Microorganisms are a significant component of beach sand. Bacteria, fungi, parasites, and viruses have all been isolated from beach sand. Some genera and species that may be encountered through contact with sand are potential pathogens. Accordingly, concern has been expressed that beach sand or similar materials may act as reservoirs or vectors of infection (Mendes et al., 1997; Roses Codinachs et al., 1988; Nestor et al., 1984), although transmission by this route has not been demonstrated in epidemiological studies.

The high values obtained for the total aerobic count for soil and water samples at the two sites is alarming. Suntan Beach is a government-owned tourist resort and the level of hygiene there is low when compared with that of the privately-owned Whispering Palms. Garbage baskets were dumped in one corner in front of Suntan Beach while garbages gathered at Whispering Palms are usually carried to dumping sites very far from the resort. Seepage of nutrients from the piled up garbages eventually goes into the soil. This may be the reason for the higher value obtained for Suntan Beach. Khiyama and Makemson (1973) stated that the growth of microorganisms in beach sand is limited by the nutrient input. Laboratory studies have shown that nutrients pass through the bacterial community into the protozoan and metazoan community. Further studies have shown that microbial contamination is higher in the sand than in adjacent waters, as the sand behaves as a passive harbor for cumulative pollution (Oshiro and Fujioka, 1995; Oliveira and Mendes, 1992, 1991).

This study concluded that the contaminated sand could be the major source of the periodically high levels of bacteria in the water. (Oshiro and Fujioka, 1995; Figueras et al., 1992, and Aubert et al., 1987). From the results obtained the mean total coliform count and mean total aerobic count of beach soil is higher than that obtained from the recreational water. This is consistent with the result obtained by Aulicino et al., (1985). In his study, a significant correlation was found between contamination of beaches and contamination of adjacent seawaters, although the sand had higher bacterial counts than the water. Ghinsberg et al., (1994) is also in consonance with the results obtained in this work. He recorded low levels of Campylobacter jejuni in both coastal glasses of water and sand on some Israeli beaches, with the beach sand containing higher counts than adjacent shore waters. A similar tendency was found at Barcelona beaches; in contrast to the result obtained by Aulicino et al., (1985), however, the level of contamination was not significantly different between sand and seawater (Roses Codinachs et al., 1988). However, the mean obtained from samples exceed the standard for recreational water by EPA, which should not exceed 500cell/10oml for soil and water. (Israa, 2013)

\subsection{CONCLUSION AND RECOMMENDATION}

Based on the findings from this research, it can be concluded that demographic variables do not influence decisions of sampled respondents from the two study sites. 
Also from the results obtained regarding environmental management, facilities, and services, Whispering Palms stood out when compared with Suntan Beach. However, regarding soil and water quality, the two results obtained did not meet up to the standard of (US EPA) on the quality of recreational environments. It is therefore recommended that educational campaigns on hygiene and sanitation be carried out in the society. This is very paramount to obtain an environment with reduced level of disease-causing bacteria. Development of safety and security polices for tourism and improvement of infrastructures should be encouraged, especially for the government-owned recreational centers.

Also, renovation of the bad road leading to Whispering Palms to encourage tourists to patronize the recreational site is encouraged and the construction of cheap eco-lodges at Suntan Beach is suggested.

\section{REFERENCES}

Adewale AA, (2015). Economic and socio-cultural tourism indicators for Suntan Beach, Badagry. MSc project, University of Ibadan, Department of Wildlife and Ecotourism Management.

Al-Jebouri MA., Edham MH.,(2012). An Assessment of Biological Pollution in Certain Sectors of Lower AlZab and River Tigris Waters using Bacterial Indicators and Related Factors in Iraq. Journal of Water Resource and Protection, 4:32-38.

Aubert M., Mathonnet S., Gillemaut, C., (1987). Dépollution des plages par l'eau de mer éléc-trolysée. Effects sur les micro-organismes pathogènes. [Cleaning of beaches with electrolysed seawater. Effects on pathogenic microorganisms.] Revue Internationale d'Océanographi Médi-cale, 85-86: 222-227.

Aulicino FA., Volterra L., Donati G., (1985) Faecal contamination of shore-line sands. Bollet-tino della Società Italiana di Biologia Sperimentale, 61(10): 1469-1476.

Do Valle PO, Silva JA, Mendes J, Guerreiro, M. (2006). Tourist Satisfaction and Destination Loyalty Intention: A structural and categorical anal. Retrieved June 28, 2011 from http://www.business-andmanagement.org.

Figueras MJ, Guarro J, Soler L, Inza I, Polo F, 1992. Estudio piloto sobre la contamination de las playas del litoral Catalan. [A pilot study on the contamination of Catalounian beaches.] Proceedings of the $1^{\circ}$ Congreso Nacional del Medio Ambiente, Madrid.

Ghinsberg RC, Leibowitz P, Witkin H, Mates A, Seinberg Y, Bar DL, Nitzan Y, Rogol M(1994) Monitoring of selected bacteria and fungi in sand and seawater along the Tel-Aviv coast. Athens, United Nations Environment Programme, Mediterranean Action Plan, pp. 65-81(MAP Technical Reports Series No. 87)

Guidelines for safe recreational water environments .Volume 1: Coastal and Fresh Waters World Health Organization, 2003.

Ibimilua AF.,(2009). Tourism Participation: Attractions, Influences and Key Trends in Ekiti State, Nigeria. African research review. vol.3 (3): 244-258.

Ibrahim KO., Okunlola IA., Abdurrahman A., (2013) Trace metal indices in the characterization of hydrogeochemical condition of surface water along Asa River, Ilorin, Kwara State, Nigeria. Int. J. Geol. Earth Environ. Sci., 3 (1), pp. 29-35.

Israa AJ., Mahmoud I., Yaseen AJ.,(2013). Estimation of validity Tigris River Water for Swimming in Baghdad City. Advances in Physics Theories and Applications .Vol.18.

Khiyama HM., Makemson JC., (1973). Sand beach bacteria: enumeration and characterization. Applied Microbiology, 26(3): 293-297.

Mendes B., Urbano P., Alves C., Lapa N., Norais J., Nascimento J., Oliveira JFS., (1997) Sanitary quality of sands from beaches of Azores islands. Water Science and Technology, 35(11- 12);147-150.

Mobee OR, (2014). Tourism potentials of Badagry Local Government area, Lagos -State. BSc project, University of Ibadan, Department of Wildlife and Ecotourism Management.

Nestor I., Costin-Lazar L., Sovrea D., Ionescu N., (1984). Detection of enteroviruses in sea water and beach sand. Zentralblatt für Bakteriologie, Mikrobiologie und Hygiene Abteilung 1, 178(5-6):527-534.

Okhuysen P.C., Chappell CL., Crabb JH., Sterling CR., DuPont HL., (1999). Virulence of three distinct Cryptosporidium parvum isolates for healthy adults. J. Infect. Dis. 180:1275-1281. 
Olaoluwa OD., (2015). Assessment of tourism development services of Whispering palms, Badagry, Lagos- State. BSc project, University of Ibadan, Department of Wildlife and Ecotourism Management.

Olayiwola, AW, (2014). Assessment of tourism potentials of Lagos -State, Nigeria. BSc project, University of Ibadan, Department of Wildlife and Ecotourism Management.

Oliveira JS, Mendes BS, 1992. Qualidade da Agua do Litoral Portugues. [Water quality inPortugal.] $1^{\circ}$ Congresso da Agua, Vol. 2.Lisbon, Portuguese Association of Water Resources (APRH), 155-179.

Oliveira JS., Mendes BS., (1991). Poluicao das praias e zonas litorais: Medidas cauterales e normasde qualidade.Reuniaö o sobre a Gestaö Municipal e a Gestaö da Agua.[Pollution of beaches and coastal areas: preventive measures and quality standards. Meeting on Management of Municipalities and Water Management.] Cascais, Portuguese Association of Water Resources (APRH)/Municipality Service of Water and Sanitation (SMAS).

Oshiro R., Fujioka R., (1995). Sand, soil, and pigeon droppings: sources of indicator bacteria in the waters of Hanauma Bay, Oahu, Hawaii. Water Science \& Technology 31(5):251-254 •

Roses Codinachs M., Isern Vins AM., Ferrer Escobar MD., Fernandez Perez, F., (1988). Microbiological contamination of the sand from the Barcelona city beaches. Revista de Sanidad eHigiene Publica, 62(5-8): 1537-1544.

Silva JS, Leal, MMV, Arau' jo, MCB, Barbosa, SCT, Costa, South East Beach Management Group (2006). Minutes of Twelfth Meeting, Brighton and Hove City Council.http://www.nationalbeachsafetyorg.uk/advisorygroup/documents/SEBMG_SEPTo6.pdf

Storrier KL., McGlashan DJ., Bonellie S., Velander K.,( 2007). Beach litter deposition at a selection of beaches in the firth of forth, Scotland. Journal of Coastal Research 23, 813-822.

Tudor DT., Williams AT., (2008). Important aspects of beach pollution to managers: Wales and the Bristol Channel, UK. Journal of Coastal Research, Volume 24, Issue 3: 735-745. doi: http://dx.doi.org/10.2112/06-0727.1

UNWTO (2004). Guidebook on Indicators of Sustainable Development for Tourism Destinations eISBN: 97892-844-0726-2.

USEPA, (2002) Great Lakes strategy 2002-a plan for the new millennium. Promoting clean and healthy beaches. [Online.] http://www.epa.gov/grtlakes/gls/glso4.html.

Whitman R.L., Nevers M.B., (2003). Foreshore sand as a source of Escherichia coli in nearshore water of a Lake Michigan beach. Appl. Environ. Microbiol. 69:5555-5562.

Wikipedia (2015). Map of Badagry, assessed on October $27^{\text {th }} 2015$

\section{APPENDIX}

In-Depth Interview with the Key Informants (Suntan Beach and Whispering Palms)

Analysis of interview on Environmental quality

Theme 1: Are there factories around the resort centre that emit large quantities of polluted substances?

Suntan beach: no (Mr Yusuf isa'n)

Whispering palms: not at present (Mr Oluwafunmi)

Theme 2: What method do you use in collecting and disposing communal waste?

Suntan beach: waste bin and it is disposed outside the resort centre where it is usually burned there. (Mr Yusuf isa'n)

Whispering palms: we all make use of waste bin, which is located everywhere around the resort. (Mr Oluwafunmi)

Theme 6: How do you dispose refuse/wastes from the resort centre?

Suntan beach: the refuse/wastes are usually burnt outside the premises (Mr Yusuf isa'n)

Whispering palms: the wastes are usually gathered and transferred to another location far from the resort centre and burnt (Mr Oluwafunmi)

Theme 7: What method do you use in cleaning water and bushes around the resort centre? 
Suntan beach: Lawn mowers are use for cutting grasses and also manual labour (Mr Yusuf isa'n)

Whispering palms: Manual labour is usually employed to remove water hyacinth while cutting of grasses within and around the premises are done majorly using lawn mower and at times manual labour (Mr Oluwafunmi)

\section{Facilities and services}

Theme 1: Which periods do you experience overcrowding and congestion most at the resort centre?

Suntan beach: during festive periods such as Oloku, Chrismas, lleya, New Year etc. The influx of tourists used to be very high. (Mr Yusuf isa'n)

Whispering palms: during vacations, special holidays, and so on. (Mr Oluwafunmi)

Theme 2: How do you manage tourists activities when there is overcrowding, in terms of facilities (recreational facilities, convenience etc)?

Suntan beach: the beach is very large, so there is usually space for tourists. Also, tourists do not come at the same time. Many of them play games together there, meeting new friends at the beach. (Mr Yusuf isa'n)

Whispering palms: there are lots of facilities for tourists and it is not possible to be playing two games at the same time. In that case there will be one game or the other available for tourists. (Mr Oluwafunmi)

Theme 3: What is the total number of convenience provided for tourists?

Suntan beach: total of 10(two inside and eight outside at the car park) (Mr Yusuf isa'n)

Whispering palms: apart from the ones in the chalet and suits, there are about fifteen located at different places. (Mr Oluwafunmi)

Theme 4: What is the total number of tourists during peak periods?

Suntan beach: about 5,000 plus. (Mr Yusuf isa'n)

Whispering palms: 2,000 tourists on the average (Mr Oluwafunmi)

Theme 5a: Do you have catering unit that render services to tourist?

Suntan beach: no, tourists come with their food and can also buy from food vendors around the beach (Mr Yusuf isa'n)

Whispering palms: yes, there is catering services that provide various delicacies for our guests because tourists are not allowed to come in with their food. The reason is that we have a standard catering unit and also it a business enterprise so we generate more income for the resort. (Mr Oluwafunmi)

Theme 5b: If no, is there any local restaurant or eating outlet around that cater for tourists?

Suntan beach: we have food vendors and also shops that render food and various types of drinks services to tourist. (Mr Yusuf isa'n)

Theme 6: How does the eating outlet dispose their waste?

Suntan beach: outside the beach were the ones that are generated from the beach are disposed (Mr Yusuf isa'n)

Whispering palms: all the wastes generated from the resort is disposed together. (Mr Oluwafunmi)

Theme 7: What is the number of chalets in your resort centre that cater for tourists who intends to stay for more than a day?

Suntan beach: we have 10 chalets which is room and parlour. (Mr Yusuf isa'n)

Whispering palms: we have about 122 en-suite rooms which spread across various buildings on the premises. (Mr Oluwafunmi)

Theme 8: Do you have hotels near you that provide accommodation for tourist during peak periods?

Suntan beach: yes, there is Eddy West hotels (Mr Yusuf isa'n)

Whispering palms: yes, Onimoba garden city hotel (Mr Oluwafunmi)

Theme 9: Have you recorded any form of food poisoning?

Suntan beach: no, not at all (Mr Yusuf isa'n)

Whispering palms: nothing of such (Mr Oluwafunmi) 